УДК 378.147:004.6.377

Саварин Павло Вікторович

асистент кафедри комп'ютерних технологій

Луцький НТУ, м. Луцьк, Україна

savaryn.pasha@lntu.edu.ua

\title{
ОСОБИСТІСНО-ОРІЄНТОВАНА СИСТЕМА ПІДГОТОВКИ ФАХІВЦІВ ТЕХНІЧНОГО ПРОФІЛЮ 3 ВИКОРИСТАННЯМ МЕДІАТЕХНОЛОГІЙ
}

\begin{abstract}
Анотація. У статті висунуто проблему навчання протягом життя. Здійснено короткий аналіз парадигм підготовки майбутнього фахівця до професійної діяльності. Детально охарактеризовано особистісно-оріснтовану систему підготовки і здійснено аналіз останніх досліджень i публікацій, що стосуються даного питання. Проаналізовано модель особистісно-орієнтованого навчання у вищому технічному навчальному закладі й наголошено на важливості використання різноманітних джерел наукової інформації для кожного студента. Розкрито і дано коротку характеристику суті поняття «медіатехнології». Проведено розгляд важливих принципів, які мають зацікавити викладачів використовувати медіатехнології у своїй професійній діяльності. Описано основні вимоги, до розробки дидактичного забезпечення, яких рекомендовано дотримуватись, використовуючи медіатехнології як допоміжний засіб навчання. Відзначено важливу роль викладача вищого технічного навчального закладу у впровадженні основних складових особистісноорієнтованої системи підготовки 3 використанням медіатехнологій. Розкрито якості, які необхідно розвивати в стінах технічного вузу у студентів.
\end{abstract}

Ключові слова: особистісно-орієнтована система; медіатехнології; вищий технічний навчальний заклад; фахівець технічного профілю; професійна діяльність.

\section{1. ВСТУП}

Постановка проблеми. Змінився час, змінюються й вимоги до людини, iї освіченості. Починаючи зі школи, треба навчити людей вчитися упродовж життя, використовувати здобуті знання на практиці. Суспільство потребує виховання творчої особистості, здатної самостійно мислити, пропонувати оригінальні ідеї, приймати сміливі, нестандартні рішення. Тому орієнтиром змісту освіти $\epsilon$ розвиток особистості [9].

Особистісно-орієнтований підхід нині досить яскраво заявляє про себе у педагогічній науці, його складові забезпечують створення нових механізмів навчання i виховання та грунтуються на принципах глибокої поваги до особистості, самостійності особи, врахування їі індивідуальності.

Зростання потреби в даних і збільшення потоків різноманітних відомостей у людській діяльності зумовлює розробку і використання електронних засобів. Нові інформаційні технології, якими $є$ глобальна комп'ютерна мережа Інтернет, мультимедійні комп'ютерні системи, IP-телефонія, цифрове телебачення, супутникове і кабельне телебачення та ін., зумовили радикальні зрушення у всіх сегментах соціальної взаємодії. У наш час, обмін відомостями, які подані за допомогою медіатехнологій, перевищує 11 годин у день, телевізор включений у квартирах / будинках у середньому 7 годин 38 хвилин щодня, а діти від двох до дванадцяти років у середньому дивляться телевізор 25 годин на тиждень [10].

Досить широко інтегрувалися медіатехнології і в педагогічну діяльність. Отже, медіатехнології з кожним роком відіграють все більшу роль у житті людей взагалі, і в освітньому процесі зокрема. Не тільки національні наукові школи, але й окремі дослідники пропонують свої варіанти трактувань таких понять, як «медіатехнології» 
(media technology), «мультимедіа» (multimedia), «медіаосвіта» (media edication), «медіаграмотність» (media literacy) і «медіакультура» (media culture).

Проте, хоча особистісно-орієнтована парадигма і медіатехнології $\epsilon$, на даний час, досить непогано досліджені як закордонними, так і вітчизняними науковцями, поєднання даних педагогічних систем у навчальному процесі практично не досліджено.

Аналіз останніх досліджень і публікацій. Наукові передумови виникнення особистісно-орієнтованого підходу поступово визначались у різноманітних дослідженнях особистості.

Із самого початку, використовуючи гуманістичний підхід (спочатку в межах гуманістичної психології), вчені займалися вивченням можливостей і обдарувань людини. Пізніше за допомогою гуманістичного підходу аналізували такі явища, як любов, творчість, «Я» розвиток, організм, реалізація власних можливостей, вищі цінності буття, становлення, спонтанність, досвід, психічне здоров'я тощо. Цей підхід метою свого вивчення зробив здорового, творчого індивіда. На сьогоднішній день 3 ним пов'язані імена К. Гольдштейна, А. Маслоу, Дж. Олпорта, К. Роджерса, Р. Мея, Е. Фрома, К. Хорні, В. Франкла, Р. Бернса та ін. [2].

У 70-90-ті роки питання необхідності особистісного підходу у психології і педагогіці неодноразово порушувались у працях В. О. Сухомлинського, I. С. Кона, А. В. Петровського, Б. О. Федоришина, І. Д. Беха та ін.

Особистісний підхід доцільно розглядати як важливий психолого-педагогічний принцип, як методологічний інструментарій, основу якого становить сукупність вихідних концептуальних уявлень, цільових установок, методико-психодіагностичних та психолого-технологічних засобів, які забезпечують більш глибоке цілісне розуміння, пізнання особистості студента і на цій основі — iї гармонійний розвиток в умовах існуючої системи освіти [1, 12-15]. Сучасні вимоги до формування цієї освітньої технології визначалися у дослідженнях В. О. Сухомлинського, Я. Ф. Чепіги, І. Д. Беха, О. Я. Савченко, О. М. Пехоти та ін.

Різні питання медіатехнологій i медіаосвіти досліджували Л. М. Баженова, А. В. Фєдоров, Б. С. Гершунський, JI. С. Зазнобіна, I. А. Фатєєва, Є. В. Вохришева, А. О. Новікова, С. С. Полат, Ю. Н. Усова, А. В. Хуторський та ін. У роботах Д. Браун, Д. Бекінгема, Д. Сіменса, У. Карлсона, Р. К’юбі, Л. Мастермана, А. Мінккінена тощо, розкривається специфіка медіатехнологій і медіаосвіти, їх ключові аспекти.

Мета статті. Особистісно-орієнтовану систему підготовки фахівців технічного профілю можна визначити як створення таких умов у вищих технічних навчальних закладах, які б сприяли розвиткові особистісних якостей і подальшому зростанню їх професійної компетентності і майстерності, а також включення медіатехнологій у процес підготовки майбутніх фахівців.

Тому метою статті є таке: здійснити опис і коротко охарактеризувати поняття «медіатехнології», розкрити педагогічні умови, що сприяють розвитку особистісноорієнтованої системи підготовки фахівців технічного профілю. А також описати можливості поєднання особистісно-орієнтованої системи і медіатехнологій у єдине ціле для підготовки висококваліфікованих фахівців.

\section{2. МЕТОДИ ДОСЛІДЖЕННЯ}

$\begin{array}{llrrr}\text { У } & \text { дослідженні } & \text { поставленої } & \text { проблеми застосовувався } & \text { комплекс } \\ \text { взаємодоповнюючих загальнонаукових } & \text { теоретичних методів: } & \text { теоретико- } \\ \text { методологічний аналіз наукових робіт, що відображають стан вивченості проблеми } \\ \text { використання особистісно-орієнтованої системи в процесі підготовки фахівців } \\ \text { технічного профілю у вищій школі, розвитку медіатехнологій і впливу їх на людину; }\end{array}$


метод порівняльного аналізу різноманітних особистісно-орієнтованих систем підготовки фахівців технічного профілю в пострадянських і провідних країнах світу; метод експертних оцінок; аналіз та узагальнення особливостей використання медіатехнологій в освітньому процесі, а також їх вплив на студентів; відпрацювання інформації про результати впровадження особистісно-орієнтованої системи навчання в освітній процес.

\section{3. РЕЗУЛЬТАТИ ДОСЛІДЖЕННЯ}

Освіта, яка не вчить жити успішно в сучасному світі, не має ніякої цінності. Кожен із нас приходить у життя з природженою здатністю жити успішно й щасливо. А ми маємо збагатити цю здатність знаннями і навичками, які допомогли б нам iii реалізувати якомога ефективніше [5].

Мистецтво викладання видозмінюється в мистецтво навчити студентів того, як слід самостійно вчитися. Сьогоднішні студенти — це перше покоління, що виросло у світі цифрових інформаційних технологій.

Орієнтація навчання на особистість передбачає створення у вищому навчальному закладі оптимальних умов використання різних джерел наукової інформації для кожного студента під час опанування знань.

Використання моделі особистісно-орієнтованого навчання дає можливість розв'язати такі проблеми:

- створення «суб'єкт-суб' єктних» стосунків між викладачем і студентом;

- запровадження педагогіки співробітництва, співдружності, діалогу;

- створення умов для самостійної роботи студентів 3 вивчення навчального матеріалу;

- створення умов для роботи із студентами з різним рівнем розумових здібностей та індивідуальними ритмами.

Працюючи над розробкою моделей занять, треба прагнути побудувати їх на оптимальному поєднанні традиційних, перевірених часом принципів дидактики, таких як науковість, відповідність віковим особливостям, особистісно-орієнтоване навчання і використанням медіатехнологій.

Ознаками цих моделей $\epsilon$, на нашу думку, такі:

- студент усвідомлює мету заняття як важливу особисто для себе;

- засвоєння знань відбувається переважно під час активної діяльності студентів на лабораторному чи практичному занятті, наразі студенти працюють над теоретичними відомостями і виконують практичну частину, використовуючи медіатехнології;

- студент - особистість 3 власним досвідом, тому результативність навчання значною мірою залежить від уміння використовувати свій індивідуальний досвід під час виконання самостійної роботи на предмет знання основ роботи 3 певним видом обладнання, навчальних симуляторів тощо;

- ефективне навчання не може бути нудним - навчання майбутніх кваліфікованих фахівців має відбуватися 3 використанням різноманітної цікавої інформації і професійного викладу актуальних відомостей.

Розглянемо детальніше, що ж таке медіатехнології. Вони супроводжують людину давно і їх умовно поділяють на п’ять типів: ранні (писемність), друковані (друкарство, літографія, фотографія), електричні (телеграф, телефон, звукозапис), мас-медіа (кінематограф, телебачення), цифрові (комп'ютер, інтернет) [4].

Як відомо, медіа (англ. media - засоби, способи) — це канали й інструменти, що використовуються для зберігання, передавання і подання певного набору даних. Термін 
часто згадується як синонім мас-медіа або новинних медіа, але у ширшому розумінні означає єдине середовище, яке використовується для передавання будь-яких даних 3 будь-яких цілей [14]. Медіа виступає посередником у передаванні даних від одного адресата до іншого. У педагогічній літературі поняття «медіа» вживається стосовно допоміжних наукових і технічних засобів, які використовуються в навчанні.

Слово медіа часто вживається як глобальне поняття, що охоплює як дидактичні засоби, наукову підтримку, так і засоби масової комунікації. Отже, медіа — це предмети, обладнання і носії, що передають певні дані (комунікати) через слова, зображення і звуки, і дозволяють ці дані опрацьовувати, зберігати та передавати далі [6].

Медіатехнології - це поєднання різноманітних «медіа» для донесення необхідних даних до оточуючих, використовуючи при цьому різноманітні способи (усні, технічні) і прийоми (педагогічні, психологічні) [12].

Одним із видів медіа-даних є динамічні медіа-дані, що є потоковими даними, які змінюються у кожен момент часу. Динамічні дані включають в себе три джерела надходження: текстова стрічка, Web-камери та аудіодатчики. Завдяки широкому розповсюдженню WWW (World Wide Web) гіпертекстову технологію знають або, принаймні, використовують всі, хто працює на комп'ютері. В основі WWW лежить технологія гіпертексту - нелінійної форми запису текстових даних з позначенням посилань на фрагменти тексту будь-якого документа, що знаходиться в автоматизованій інформаційній системі, і можливістю швидкого переходу до цих фрагментів. Посилання можуть включати не тільки текстові дані, але і графічні, аудіо-, відео- та ін. Для такого роду документів вже використовується гіпермедіа, забезпечуючи зв'язок між мультимедійними об' єктами.

Комп'ютеризація й інтернетизація суспільства відбуваються паралельно із затвердженням нових стилів праці, нових цінностей, інформаційної різноманітності, i ці зміни не зводяться тільки до технічної сфери, вони носять глобальний характер, проникаючи в усі сфери життєдіяльності людей.

Відомо, що в процесі навчання студентами освоюється не більше, ніж чверть пропонованого матеріалу. Медіатехнології дозволяють в 2-3 рази збільшити цей показник, оскільки це надає можливість синергетичного навчання, тобто одночасно зорового і слухового сприйняття матеріалу, активної участі в управлінні його поданням, повернення до тих розділів, які вимагають повторного аналізу [11]. Медіатехнології сьогоднішнього покоління пропонують користувачам безліч варіантів індивідуального налаштування, освоюючи навчальний матеріал, студент сам встановлює швидкість вивчення, обсяг матеріалу і ступінь його складності. Економія часу, необхідного для вивчення конкретного матеріалу, у середньому складає 30 \%, а придбані знання зберігаються в пам'яті значно довше.

Отже, медіатехнології в навчанні будемо розуміти як систему, яка включає проектування, організацію та проведення занять із забезпеченням багатоканальності сприйняття відомостей суб'єктами навчання в інтерактивному режимі за рахунок використання мультимедійних комп'ютерних апаратно-програмних і мультимедійних навчальних програмних засобів. Загальна мета медіатехнологій полягає в доборі та застосуванні пов'язаних між собою засобів (медіа) так, щоб постійно вдосконалювати і збільшувати обсяг даних, до яких мають доступ користувачі.

У цьому контексті доречним буде згадати МООС системи. Вікіпедія пропонує таке визначення MOOC: «A massive open online course (MOOC) is an online course aiming at large-scale interactive participation and open access via the web ...». «Масовий відкритий онлайн курс - це курс, який передбачає велику кількість учасників і відкритий доступ через інтернет. На додаток до традиційних матеріалів, таких як відео, 
лекції та проблемні завдання, МООС надає інтерактивні форуми, щоб створити спільноту для студентів і викладачів» [13].

Спробуємо розібратися, яка відмінність між словами мультимедіа і медіа (під медіа будемо розуміти медіатехнологіï). Частенько ці поняття плутаються або використовуються в розумінні одного і того ж. Іноді грань, дійсно, дуже розмита, але вона все ж є присутньою. Обидва слова використовуються дуже часто, в абсолютно різних випадках і в різних варіантах. Їх можна зустріти, як частини складених слів або словосполучень, наприклад, медіасервер, мультимедійний файл та ін. Також в Інтернеті багато інформації, що розповідає, як про історію походження цих слів, так і їх значення.

У результаті опрацювання літературних джерел, у яких висвітлюється дане питання, доречно зробити висновок, що в медіатехнологіях більша увага надається способу взаємодії і передаванню інформації в соціумі. Тоді як мультимедіа ж, у свою чергу, приділяє більше уваги і є наближеним поняттям до інформаційних технологій, комп'ютерних зображень, передаванння відео по мережі інтернет, ігор, інтерактивної взаємодії користувачів. Також мультимедіа може включати 2D i 3D технології. Тобто мультимедіа описує, як технічно зробити передавання даних у соціумі, охоплюючи способи подання різних видів даних - звукові, текстові, графічні, відео, анімаційні, можливо, в одній системі чи в поєднанні.

У цьому контексті викладачів технічних дисциплін необхідно зацікавити використовувати медіатехнології на заняттях, а студентів під час самостійної роботи, тому, на наш погляд, доречним буде:

- надання студентам свободи вибору варіантів завдань, способів їх виконання, форм звіту про результати виконаної роботи, при цьому на всіх етапах роботи потрібно заохочувати студентів використовувати медіатехнології для виконання поставленого завдання;

- на парах оцінювати механізм творчості студентів, завдяки якому досягається результат - не настільки важливо досконало знати якусь певну технологію, як важливим є здатність поєднати певні технології і знання для створення чогось нового;

- найважливішим джерелом мотивації є потреби й інтереси самих студентів, а тому потрібно зацікавити їх самостійно знаходити цікаві й актуальні дані, відповіді на важливі питання і т. д. Саме в цьому аспекті використання медіатехнологій може стати хорошим стимулом для зацікавлення.

Позитивне налаштування на заняття значною мірою залежить від спланованої мети: «Що, навіщо, за допомогою яких технологій ми будемо вивчати? Де можна використати ці знання»? Спостереження показують, що найбільший інтерес викликає пов'язування матеріалу 3 очевидними явищами i практичним використанням у майбутньому [8].

Особливого значення набуває при цьому позитивний зворотний зв'язок, оцінка зусиль, створення ситуації успіху. Раціональний вибір методів і їх застосування обумовлений конкретною метою. Використання різних методів навчання наразі значною мірою сприяє розвитку мислення.

Вивчаючи науковий доробок вітчизняних учених, зокрема I. Д. Беха, ми переконуємося, що особистісно-орієнтований підхід потребує від викладача постійного вивчення і знання індивідуальних особливостей особистості, зокрема, темпераменту; уміння діагностувати і знати реальний рівень сформованості таких важливих особистісних якостей, як спосіб мислення, мотиви, інтереси, установки, спрямованість особистості, ставлення до життя, праці, ціннісні орієнтації, життєві плани та інші; своєчасного виявлення й усунення причин, які можуть перешкодити досягненню мети, 
а якщо ці причини не вдалося вчасно виявити й усунути - оперативно змінювати тактику виховання залежно від нових сформованих умов і обставин; розвивати самостійність, ініціативну самодіяльність студентів, не стільки керувати, скільки вміло організовувати і спрямовувати, у чому саме і допоможуть медіатехнології.

Цілі і завдання особистісно-орієнтованого навчання, яких, на нашу думку, рекомендовано досягати, використовуючи медіатехнології як допоміжний засіб навчання:

- розвивати індивідуальні і пізнавальні здібності кожного студента у різноманітних галузях технічного знання (вебінари, симулятори, тренажери, навчально-методичні комплекси);

- максимально виявляти, ініціювати, використовувати індивідуальний (суб'єктивний) досвід людини;

- допомогти студенту пізнати i зрозуміти всі напрямки обраного фаху, самовизначитися і самореалізуватися у цій сфері, а не формувати заздалегідь визначені установки.

Основні вимоги до розробки дидактичного забезпечення особистісно орієнтованої системи підготовки майбутнього викладача технічних дисциплін, яких, на нашу думку, рекомендовано дотримуватись, використовуючи медіатехнології як допоміжний засіб навчання:

- навчальний матеріал повинен забезпечувати виявлення змісту суб'єктного досвіду студента, включаючи досвід його попереднього навчання;

- виклад знань викладачем повинен бути спрямований не лише на розширення їх обсягу, структуризацію, інтеграцію, узагальнення, але й на перетворення наявного досвіду кожного студента;

- під час навчання необхідно постійно узгоджувати попередній досвід студента 3 науковим змістом нових знань, що пропонуються;

- активне стимулювання студента до самооцінної освітньої діяльності має забезпечувати йому можливість самоосвіти, саморозвитку, самовираження;

- навчальний матеріал має бути організований так, щоб студент мав можливість вибору різноманітних джерел даних;

- необхідно стимулювати студентів до самостійного вибору і використання медіатехнологій для опрацювання навчального матеріалу;

- під час уведення знань про прийоми виконання різних дій необхідно виділяти загальнологічні і специфічні предметні прийоми роботи з урахуванням їх функцій в особистісному розвитку;

- необхідно забезпечувати контроль й оцінку не тільки результату, але головним чином процесу роботи над певним видом навчального матеріалу, тобто тих трансформацій, які здійснює студент, засвоюючи навчальний матеріал 3 використанням медіатехнології.

При цьому позиція викладача полягає у:

- ініціюванні суб' єктного досвіду;

- розвитку індивідуальності кожного студента;

- визнанні індивідуальності, самобутності, самоцінності кожної людини;

- умінні і прагненні до використання медіатехнологій у професійній діяльності.

Позиція студента:

- вільний вибір навчального матеріалу, 3 яким можна ознайомитись, використовуючи медіатехнологіі;

- самопізнання, самовизначення, самореалізація.

Особистісно-орієнтована система підготовки фахівців технічного профілю 3 використанням медіатехнологій розглядається нами як складно структуроване 
багатоступеневе утворення, що забезпечує внутрішні умови для успішного формування професійної грамотності студентів технічного вузу у різноманітних сферах 3 одного боку, а з іншого - успішної реалізації особистісно-орієнтованої системи підготовки по відношенню до цих студентів.

Відповідно до цього твердження, особистісно-орієнтовану систему підготовки фахівців технічного профілю з використанням медіатехнологій можна розглянути як єдність чотирьох компонентів: когнітивного, діяльнісно-технологічного, емоційноціннісного та інтеграційного (табл. 1). Усі ці компоненти мають стати основою для викладачів, що проводять підготовку студентів.

Таблиияя 1

\section{Особистісно-оріснтована система підготовки фахівців технічного профілю 3 використанням медіатехнологій}

\begin{tabular}{|c|c|}
\hline $\begin{array}{c}\text { Когнітивний } \\
\text { компонент }\end{array}$ & $\begin{array}{l}\text { Що потрібно знати для підготовки фахівців технічного профілю? } \\
\text { Методологічні основи проблеми особистісно-орієнтованого навчання. } \\
\text { Розуміння сутності дискурсів, цілей і завдань гуманістичного навчання і виховання. } \\
\text { Засоби саморозвитку. } \\
\text { Закономірності розвитку студентів і їх індивідуально-психологічні особливості. } \\
\text { Засади і засоби особистісно-орієнтованої системи навчання. } \\
\text { Медіатехнології, їх призначення та способи використання }\end{array}$ \\
\hline $\begin{array}{l}\text { Діяльнісно- } \\
\text { технологічний } \\
\text { компонент }\end{array}$ & $\begin{array}{l}\text { Що потрібно вміти для підготовки фахівців технічного профілю? } \\
\text { Уміння аналізувати й оцінювати стан реально-існуючого педагогічного явища. } \\
\text { Уміння обгрунтовувати власну педагогічну діяльність як виховну систему. } \\
\text { Уміння саморегуляції власної особистісної діяльності. } \\
\text { Уміння діагностувати рівень знань у галузі медіатехнологій. } \\
\text { Уміння слухати співрозмовника. } \\
\text { Уміння виділяти, точно формулювати і ставити педагогічну задачу. } \\
\text { Теоретично обгрунтовано обирати медіатехнології для навчання студентів, щоб у } \\
\text { подальшому вони самі змогли вчитися використовуючи медіатехнології }\end{array}$ \\
\hline $\begin{array}{l}\text { Емоційно- } \\
\text { ціннісний } \\
\text { компонент }\end{array}$ & $\begin{array}{l}\text { Формування мотивів та цілей особистісно-орієнтованої системи підготовки. } \\
\text { Зацікавленість особистісно-орієнтованою системою підготовки. } \\
\text { Стійкій інтерес до медіатехнологій, як підгрунтя для усвідомленого вибору цих } \\
\text { технологій для донесення нових знань й умінь. } \\
\text { Стійка орієнтація на особистісний розвиток студента. } \\
\text { Усвідомлення і привласнення ціннісних гуманних орієнтацій }\end{array}$ \\
\hline $\begin{array}{c}\text { Інтеграційний } \\
\text { компонент }\end{array}$ & $\begin{array}{l}\text { Впевненість у власних професійних можливостях щодо реалізації особистісно- } \\
\text { орієнтованого навчання з використанням медіатехнологій. } \\
\text { Творче ставлення до особистісно-орієнтованої навчальної діяльності з урахуванням } \\
\text { змін в освіті й суспільстві. } \\
\text { Оволодіння навичками самопізнання і самоаналізу, саморегуляції і самооцінки, } \\
\text { самоконтролю, самоактуалізації, уміння будувати навчальний процес за допомогою } \\
\text { доступних медіатехнологій. } \\
\text { Коригування процесу власного розвитку через втілення системи медіатехнологій під } \\
\text { час педагогічної практик. }\end{array}$ \\
\hline
\end{tabular}

В останніх дослідженнях 3 проблем професійно-педагогічної підготовки майбутніх викладачів вказані ті якості, які потрібно розвивати в стінах технічного вузу: емпатія (здатність відчувати емоційний стан іншої людини, уміння співчувати), толерантність (здатність розуміти і приймати людину такою, якою вона $\epsilon$ ); здатність обгрунтовувати свої вчинки і виділяти мотиви своєї діяльності. Але одним із найважливих, на нашу думку, $€$ сукупність комунікативних, конструкторських, організаторських, технічних умінь і здатність практично і творчо використовувати їх в роботі. Вищому технічному навчальному закладові нині необхідні не просто хороші викладачі, а викладачі-технологи, викладачі-майстри, викладачі-новатори. 
Характерними рисами традиційної навчально-виховної системи вищого закладу освіти, як вказує практика, аналіз літературних джерел, кваліфікаційної характеристики і кваліфікаційної програми є замкнутість, імперативність, монологічність [3] процесу професійно-педагогічної підготовки, який передбачає виховання i навчання майбутнього фахівця технічного профілю. У цьому випадку особистісно-орієнтована система підготовки з використанням медіатехнологій розглядається нами як діяльність, що забезпечує в основному формування деяких специфічних якостей майбутнього фахівця (уміння орієнтуватися в сучасних інформаційних технологіях, здатність швидко вчитися, можливість застосовувати медіатехнології у подальшій професійній діяльності). Якості майбутнього кваліфікованого фахівця формують порівняно i відповідно із заданими в професіограмах абстрактними нормативами.

\section{4. ВИСНОВКИ ТА ПЕРСПЕКТИВИ ПОДАЛЬШИХ ДОСЛІДЖЕНЬ}

1. У наш час існує велика різноманітність систем підготовки майбутнього педагога. Однією 3 найпоширеніших і дієвих $€$ особистісно-орієнтована система. Орієнтиром цієї системи є особистість, iї розвиток та індивідуальність.

2. Вимоги до особистісно-орієнтованої системи визначили такі відомі педагоги, як В. О. Сухомлинський, Я. Ф. Чепіга, І. Д. Бех, О. М. Пехота. За особистісноорієнтованої системи підготовки викладача технічних дисциплін доцільно використовувати вільний вибір навчальних тем і блоків, доступність інтерактивних курсів у будь-який час, можливість вільно планувати час для навчання і відпочинку, спілкування з відомими людьми у певній галузі та ін. Суть цих методів при цьому зводиться до прямого чи опосередкованого використання медіатехнологій на заняттях. Такий метод, у свою чергу, призведе до розуміння студентом - майбутнім кваліфікованим фахівцем сутності медіатехнологій і подальшого їх використання у власній професійній діяльності для подальшого навчання, адже технології постійно розвиваються і змінюються.

3. Актуальними проблемами сучасних вищих технічних навчальних закладів $\epsilon$ створення відповідних педагогічних умов для професійного зростання викладачівпрактиків, сприяння всебічному усвідомленню викладачем необхідності підтримувати фаховий професійний розвиток упродовж педагогічного становлення, допомога в розумінні важливості оволодіння новими знаннями, інноваційними підходами i медіатехнологіями.

4. Зміна змісту освіти на сьогоднішньому етапі розвитку вітчизняної вищої школи веде до зміни іiі технологій, надає їй особистісної спрямованості. Технологізація особистісно-орієнтованого освітнього процесу передбачає спеціальне конструювання навчального тексту дидактичного матеріалу, методичних рекомендацій до його використання, типів навчального діалогу, форм контролю за особистісним розвитком студента в ході навчально-пізнавальної діяльності. I допомогти в цьому, на нашу думку, може використання медіатехнологій в освітньому процесі.

\section{СПИСОК ВИКОРИСТАНИХ ДЖЕРЕЛ}

1. Атутов П. Р. Технология и современное образование / П. Р. Атутов // Педагогика. — 1996. - № 2.

2. Бех І. Д. Особистісно зорієнтоване виховання: науково-метод. посіб. / І. Д. Бех. - К. : ІЗМН, 1998. $-203 \mathrm{c}$.

3. Бочелюк В. Й. Психологічна готовність вчителя до особистісно-орієнтованого навчання : дис. канд. психол. наук : 19.00.07 / Бочелюк Віталій Йосипович; Національний педагогічний ун-т ім. М. П. Драгоманова. — К., 1998. - 186 с. 
4. Горюнова О. Медиа: история экспансии. 2001. Краткий конспект курса лекций: Медиа: история экспансии / О. Горюнова [Электронный ресурс]. - Режим доступа : http://edu.of.ru/attach/17/31177.doc.

5. Кіосакі Р., Лечтер Ш. Багатий тато, бідний тато / пер. $з$ англ. Н. Шевченко-Гербіш. - К. : Светлая звезда, 2007. - 256 с.

6. Литвин А. Використання технологій мультимедіа у професійній підготовці / А. Литвин // Педагогіка і психологія професійної освіти. - 2005. - № 2. - С. 7-22.

7. Медіаосвіта та медіа грамотність : підручник / Ред.-упор. В. Ф. Іванов, О. В. Волошенюк; за науковою редакцією В. В. Різуна. - Київ: Центр вільної преси, 2012. - 352 с.

8. Міхелі С. Педагогічні ідеї В. О. Сухомлинського як концептуальна основа особистісно орієнтованого підходу // Початкова школа. - 2003. - № 9.

9. Освітні технології : навчально-методичний посібник / [О. М. Пєхота, А. 3. Кіктенко, О. М. Любарська та ін.]; за заг. ред. О. М. Пехоти. - К.: А.С.К., 2002. - 255 с.

10. Федоров А. В. Развитие медиакомпетентности и критического мышления студентов педагогического вуза / А. В. Федоров. - М. : Изд-во МОО ВПП ЮНЕСКО «Информация для всех», 2007. - 616 с.

11. Шлыкова О. В. Культура мультимедиа : уч. пособие для студентов / МГУКИ. - М. : ФАИРПРЕСС, 2004. - 415 c.

12. Media Technologies: Essays on Communication, Materiality, and Society. Tarleton Gillespie, Pablo J. Boczkowski and Kirsten A. Foot. MIT Press. Cambridge, Massachusetts. 2014.

13. Massive open online course [Електронний ресурс]. - Режим доступу : http://en.wikipedia.org/wiki/Massive_open_online_course.

14. Медіа [Електронний ресурс]. - Режим доступу : http://uk.wikipedia.org/wiki/Meдia.

Матеріал надійшов до редакиї 29.01.2015 p.

\title{
ЛИЧНОСТНО-ОРИЕНТИРОВАННАЯ СИСТЕМА ПОДГОТОВКИ СПЕЦИАЛИСТОВ ТЕХНИЧЕСКОГО ПРОФИЛЯ С ИСПОЛЬЗОВАНИЕМ МЕДИАТЕХНОЛОГИЙ
}

\author{
Саварин Павел Викторович \\ Асистент кафедры компьютерных технологий \\ Луцкий НТУ, г. Луцк, Украина \\ savaryn.pasha@lntu.edu.ua
}

\begin{abstract}
Аннотация. В статье выдвинуто проблему обучения в течение жизни. Осуществлен краткий анализ парадигм подготовки будущего специалиста к профессиональной деятельности. Подробно охарактеризовано личностно-ориентированную систему подготовки и осуществлен анализ последних исследований и публикаций, касающихся данного вопроса. Проанализирована модель личностно-ориентированного обучения в высшем техническом учебном заведении и отмечена важность использования различных источников научной информации для каждого студента. Раскрыто и дано краткое описание сущности понятия «медиатехнологии». Проведено рассмотрение важных принципов, которые должны заинтересовать преподавателей использовать медиатехнологии в своей профессиональной деятельности. Описаны основные требования, к разработке дидактического обеспечения, которых рекомендуется придерживаться, используя медиатехнологии как вспомогательное средство обучения. Отмечена важная роль преподавателя высшего технического учебного заведения по внедрению основных составляющих личностно-ориентированной системы подготовки с использованием медиатехнологий. Раскрыты качества, которые необходимо развивать в стенах технического вуза у студентов.
\end{abstract}

Ключевые слова: личностно-ориентированная система; медиатехнологии; высшее техническое учебное заведение; специалист технического профиля; профессиональная деятельность. 


\title{
PERSONALITY-ORIENTED TRAINING SYSTEM FOR ENGINEERING PROFESSIONALS USING MEDIA TECHNOLOGIES
}

\author{
Pavlo V. Savaryn \\ assistant of the Department of Computer Technologies \\ Lutsk NTU, Lutsk, Ukraine \\ savaryn.pasha@lntu.edu.ua
}

\begin{abstract}
The paper poses a problem of lifelong learning. Brief analysis of paradigms of future specialists training for their professional work is done. There has been described in detail personality-oriented training system as well as done the analysis of recent researches and publications relating to this issue. The model of personality-oriented training system in higher technical educational institution is analyzed and stressed the importance of using a variety of sources of scientific information for each student. There has been exposed and given a brief description of the essence of the "media technology" concept. The important principles for using media technologies in teacher's educational activity are considered. The basic requirements to didactic software development using media technology as supplement are presented. It is noted the important role of the teacher of higher technical educational institution in implementing the main components of personality-oriented training system using media technologies, as well as revealed the qualities that students of higher technical educational institution should develop.
\end{abstract}

Keywords: personality-oriented system; media technologies; higher technical educational institution; engineering professionals; professional activity.

\section{REFERENCES (TRANSLATED AND TRANSLITERATED)}

1. Atutov P. R. Technology and modern education / P. R. Atutov // Pedaghoghyka. - 1996. - № 2. (in Russian)

2. Bekh I. D. Individually oriented education, scientific method. guidances. / I. D. Bekh. - K. : IZMN, 1998. - 203 s. (in Ukrainian)

3. Bocheljuk V. J. Psychological readiness of teacher to student-centered learning: thesis. candidate. psychological. Science: 19.00.07 / Bocheljuk Vitalij Josypovych; Nacionaljnyj pedaghoghichnyj un-t im. M. P. Draghomanova. - K., 1998. - 186 sheets. (in Ukrainian)

4. Horyunova O. Media: history expansion. 2001. A brief summary of the lectures: Media: history expansion [online] / O. Horyunova. - Available from : http://edu.of.ru/attach/17/31177.doc (in Russian)

5. Kiosaki R., Lechter Sh. Rich Dad, Poor Dad / Translated from english N. Shevchenko-Gherbish. - K. : Svetlaja zvezda, 2007. - 256 s. (in Ukrainian)

6. Lytvyn A. The use of multimedia technologies in the training / A. Lytvyn // Pedaghoghika i psykhologhija profesijnoji osvity. - 2005. - № 2. - S.7-22. (in Ukrainian)

7. Media education and media literacy: tutorial / Red.-compiler. V. F. Ivanov, O. V. Voloshenjuk; For editorial V. V. Rizuna. - Kyiv : Centr viljnoji presy, 2012. - 352 s. (in Ukrainian)

8. Mikheli S. Teaching ideas V. O. Sukhomlynsjkogho as conceptual basis of individual approach // Pochatkova shkola. - 2003. - № 9. (in Ukrainian)

9. Educational technology: textbook / [O. M. Pjekhota, A. Z. Kiktenko, O. M. Ljubarsjka та ін.]; under the general editorship O. M. Pjekhoty. - K. : A.S.K., 2002. - 255 s. (in Ukrainian)

10. Fedorov A. V. Development of media competence and critical thinking pedagogy students / A. V. Fedorov. - M. : Izdat MOO VPP YuNESKO «Ynformatsyya dlya vsekh», 2007. -616 s. (in Russian)

11. Shlykova O. V. Culture multimedia: Textbook for students / MGUKY. - M.: FAYR-PRESS, 2004. 415 s. (in Russian)

12. Media Technologies: Essays on Communication, Materiality, and Society. Tarleton Gillespie, Pablo J. Boczkowski and Kirsten A. Foot. MIT Press. Cambridge, Massachusetts. 2014.(in English)

13. Massive open online course [online]. - Available from http://en.wikipedia.org/wiki/Massive_open_online_course (in English)

14. Media [online]. - $\quad$ Available from http://uk.wikipedia.org/wiki/\%D0\%9C\%D0\%B5\%D0\%B4\%D1\%96\%D0\%B0 (in Ukrainian). 